\title{
Digital Citizenship Students Viewed from Digital Commerce Aspect
}

\author{
Rini Triastuti, Dasim Budimansyah, Sapriya \\ Civic Education \\ Universitas Pendidikan Indonesia \\ Bandung, Jawa Barat, Indonesia \\ rini_triastuti_yk@yahoo.com
}

\begin{abstract}
The rapid development of information and communication technology has affected every aspect of human life. One area that is touched by the development of these technologies is the field of trade. Prior to the development of technology buying and selling goods or services are real, but currently buying and selling goods or services can be done electronically. It appeared that along with the development of information and communication technology, the world of commerce is also growing that adapts the technological development. This article is intended to describe the student's behavior related to the sale or buy goods electronically. Students today are digital citizens. Their daily life always intersects with digital technology. It is also apparent in the purchase of goods that been done by on-line. This study uses a sample of 280 students from five vocational high schools (Sekolah Menengah Kejuruan /SMK) in Surakarta, Central Java, namely SMK 4 Surakarta, SMK 5, SMK 6, SMK Kristen Surakarta and SMK Jaya Wisata Surakarta. Data was collected through interviews and questionnaires. The results showed that students are digital citizen and the majority of students ever make purchases online.
\end{abstract}

Keywords-students; digital commerce

\section{Students as Digital Citizens}

This study is a qualitative study using purposive sampling. Data were collected through interviews and questionnaires. Triangulation method used in this study. The analysis consists of three grooves activities carried out simultaneously: data reduction, data presentation, and conclusion. The development of technology has penetrated into all aspects of life. The development of technology has been enjoyed by all segments of the age. Currently the children's lives have been surrounded by a variety of equipment such as computers, laptops, mobile phones, play station and other digital technologies. The technology has become one with the lives of children so as to make them as digital citizens. Mossberger, Tolbert and McNeal [1] define digital citizens as those who use the internet regularly and effectively- that is, on daily basis. Research shows that students in vocational high school: SMK 4 Surakarta, SMK 5 Surakarta, SMK 6 Surakarta, SMK Kristen Surakarta, and SMK Jaya Wisata Surakarta are digital citizen. It appears from some of the following:
TABLE I. INTERNET ACCESS PLACE

\begin{tabular}{|l|c|c|c|c|c|}
\hline & $\begin{array}{c}\text { SMK } \\
\mathbf{4}\end{array}$ & $\begin{array}{c}\text { SMK } \\
\mathbf{5}\end{array}$ & $\begin{array}{c}\text { SMK } \\
\mathbf{6}\end{array}$ & $\begin{array}{c}\text { SMK } \\
\text { RISTEN }\end{array}$ & $\begin{array}{c}\text { SMK } \\
\text { JAYAWISATA }\end{array}$ \\
\hline Home & 17 & 33 & 25 & 14 & 7 \\
\hline School & 24 & 10 & 28 & 23 & 21 \\
\hline $\begin{array}{l}\text { Internet } \\
\text { cafe }\end{array}$ & 18 & 17 & 7 & 23 & 12 \\
\hline Mall & 1 & & & & \\
\hline
\end{tabular}

\section{Internet Acess Place}

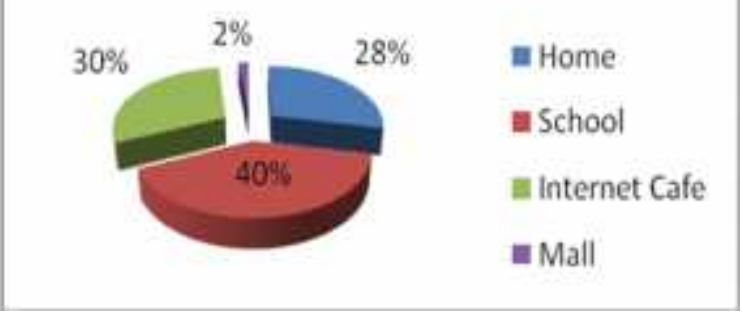

TABLE II. INTERNET ACCESS DURATION

\begin{tabular}{|l|c|c|c|c|c|}
\hline & $\begin{array}{c}\text { SMK } \\
\mathbf{4}\end{array}$ & $\begin{array}{c}\text { SMK } \\
\mathbf{5}\end{array}$ & $\begin{array}{c}\text { SMK } \\
\mathbf{6}\end{array}$ & $\begin{array}{c}\text { SMK } \\
\text { KRISTEN }\end{array}$ & $\begin{array}{c}\text { SMK } \\
\text { JAYAWISATA }\end{array}$ \\
\hline $\begin{array}{c}0- \\
\text { hour }\end{array}$ & 19 & 2 & 15 & 27 & 5 \\
\hline $\begin{array}{l}>1-2 \\
\text { hour }\end{array}$ & 22 & 10 & 23 & 13 & 17 \\
\hline $\begin{array}{l}>2-3 \\
\text { hour }\end{array}$ & 11 & 17 & 8 & 8 & 9 \\
\hline $\begin{array}{l}>3-4 \\
\text { hour }\end{array}$ & 4 & 9 & 7 & 3 & 9 \\
\hline$>4$ hour & 4 & 22 & 7 & 9 & \\
\hline
\end{tabular}

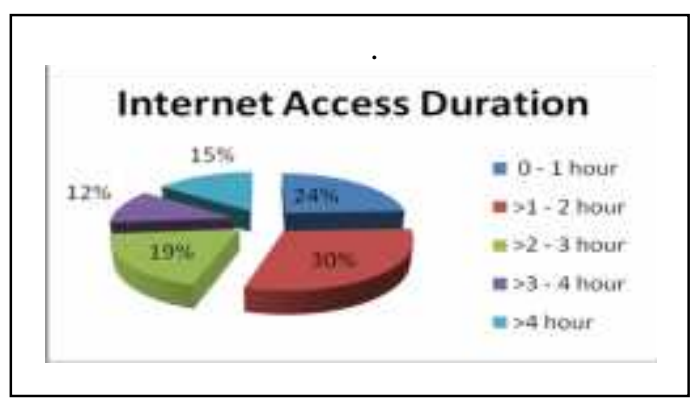


TABLE III. INTERNET ACCESS FREQUENCY

\begin{tabular}{|l|c|c|c|c|c|}
\hline & $\begin{array}{c}\text { SMK } \\
\mathbf{4}\end{array}$ & $\begin{array}{c}\text { SMK } \\
\mathbf{5}\end{array}$ & $\begin{array}{c}\text { SMK } \\
\mathbf{6}\end{array}$ & $\begin{array}{c}\text { SMK } \\
\text { KRISTEN }\end{array}$ & $\begin{array}{c}\text { SMK } \\
\text { JAYAWISATA }\end{array}$ \\
\hline $\begin{array}{l}\text { Once an } \\
\text { hour }\end{array}$ & 7 & 15 & 10 & 5 & 5 \\
\hline $\begin{array}{l}\text { Once a day } \\
\begin{array}{l}\text { Once a } \\
\text { week }\end{array}\end{array}$ & 25 & 31 & 30 & 28 & 11 \\
\hline $\begin{array}{l}\text { Once a } \\
\text { month }\end{array}$ & 8 & 14 & 15 & 9 & 19 \\
\hline
\end{tabular}

TABLE IV. INTERNET ACCESS TOOL

\begin{tabular}{|l|c|c|c|c|c|}
\hline & $\begin{array}{c}\text { SMK } \\
\mathbf{4}\end{array}$ & $\begin{array}{c}\text { SMK } \\
\mathbf{5}\end{array}$ & $\begin{array}{c}\text { SMK } \\
\mathbf{6}\end{array}$ & $\begin{array}{c}\text { SMK } \\
\text { KRISTEN }\end{array}$ & $\begin{array}{c}\text { SMK } \\
\text { JAYAWISATA }\end{array}$ \\
\hline Computer & 12 & 17 & 15 & 12 & 15 \\
\hline Netbook & 20 & 14 & 8 & 5 & 9 \\
\hline Tablet & 1 & & 2 & & 16 \\
\hline $\begin{array}{l}\text { Mobile } \\
\text { Phone }\end{array}$ & 27 & 29 & 35 & 43 & \\
\hline
\end{tabular}

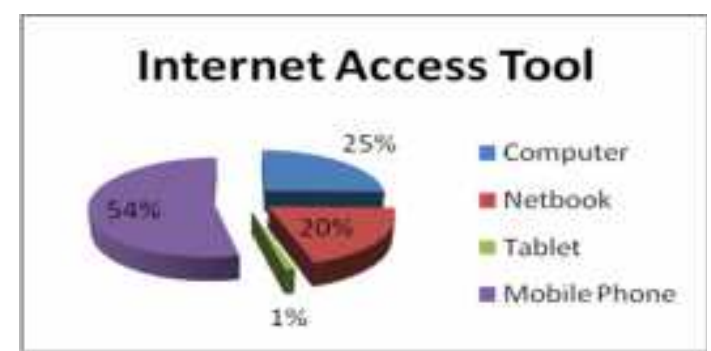

TABLE V. INTERNET ACCESS CONNECTION

\begin{tabular}{|l|c|c|c|c|c|}
\hline & $\begin{array}{c}\text { SMK } \\
\mathbf{4}\end{array}$ & $\begin{array}{c}\text { SMK } \\
\mathbf{5}\end{array}$ & $\begin{array}{c}\text { SMK } \\
\mathbf{6}\end{array}$ & $\begin{array}{c}\text { SMK } \\
\text { KRISTEN }\end{array}$ & $\begin{array}{c}\text { SMK } \\
\text { JAYAWISATA }\end{array}$ \\
\hline Wifi & 29 & 16 & 30 & 42 & 13 \\
\hline Modem & 5 & 10 & 8 & 11 & 3 \\
\hline $\begin{array}{l}\text { Mobile } \\
\text { Phone }\end{array}$ & 24 & 29 & 22 & 4 & 15 \\
\hline Others & 2 & 5 & & 3 & 9 \\
\hline
\end{tabular}

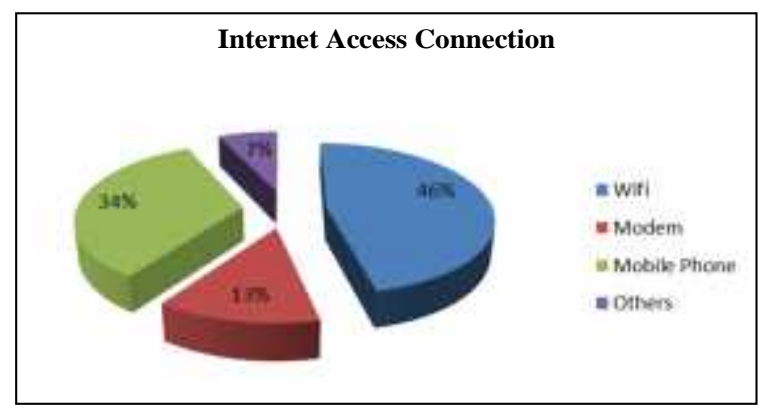

TABLE VI. SOCIAL MEDIA POSSESSES

\begin{tabular}{|c|c|c|c|c|c|}
\hline & $\begin{array}{c}\text { SMK } \\
\mathbf{4}\end{array}$ & $\begin{array}{c}\text { SMK } \\
\mathbf{5}\end{array}$ & $\begin{array}{c}\text { SMK } \\
\mathbf{6}\end{array}$ & $\begin{array}{c}\text { SMK } \\
\text { KRISTEN }\end{array}$ & $\begin{array}{c}\text { SMK } \\
\text { JAYAWISATA }\end{array}$ \\
\hline Yes & 59 & 60 & 59 & 59 & 30 \\
\hline No & 1 & & 1 & 1 & 10 \\
\hline
\end{tabular}

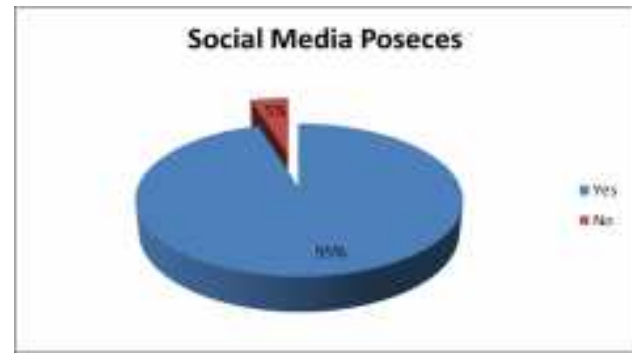

TABLE VII. FREQUENCY SOCIAL MEDIA ACCESS

\begin{tabular}{|l|c|c|c|c|c|}
\hline & $\begin{array}{c}\text { SMK } \\
\mathbf{4}\end{array}$ & $\begin{array}{c}\text { SMK } \\
\mathbf{5}\end{array}$ & $\begin{array}{c}\text { SMK } \\
\mathbf{6}\end{array}$ & $\begin{array}{c}\text { SMK } \\
\text { KRISTEN }\end{array}$ & $\begin{array}{c}\text { SMK } \\
\text { JAYAWISATA }\end{array}$ \\
\hline $\begin{array}{l}\text { Once } \\
\text { an } \\
\text { hour }\end{array}$ & 10 & 14 & 26 & 10 & 11 \\
\hline $\begin{array}{l}\text { Once a } \\
\text { day }\end{array}$ & 33 & 38 & 30 & 32 & 11 \\
\hline $\begin{array}{l}\text { Once a } \\
\text { week }\end{array}$ & 14 & 8 & 3 & 13 & 13 \\
\hline $\begin{array}{l}\text { Once a } \\
\text { month }\end{array}$ & 3 & & 1 & 5 & 5 \\
\hline
\end{tabular}

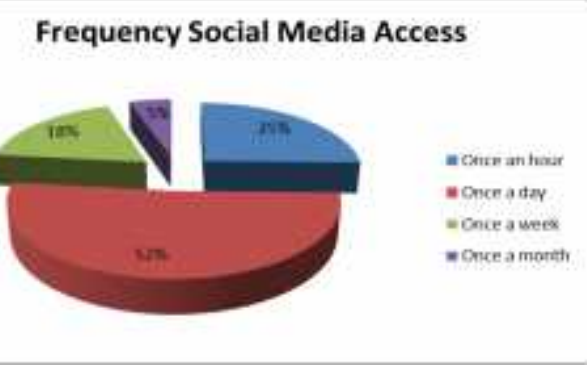

\section{Digital Citizenship STUDENTS FROM DigitAL COMMERCE ASPECTS}

Ribble and Bailey [2] define digital citizenship as the norms of appropriate, responsible behavior with regard to technology use. They identified nine elements digital citizenship as follows: digital access, digital commerce, digital literacy, digital etiquette, digital law, digital rights and responsibilities, digital health and wellness, digital security.

Given the wide scope of digital citizenship, then this paper intends to review one of the elements of digital commerce. Because among all of the elements these elements are the most difficult. Ideally, all the teachers are trying to build digital citizenship, but it is still sporadic.

The elements of digital citizenship has grown by several related subjects. For example, the subjects of information and communication technologies which have the aim that learners have the following capabilities: 1. understanding the information and communication technology; 2. developing the skills to exploit information and communication technology; 3. developing the critical attitude, creative, appreciative and independent in the use of information and communication technologies; 4. The respect of copyright works in the field of information and communication technology. 
Furthermore, the scope of the subjects of information technology and communication contains aspects as follows: 1 . the hardware and for software used to collect, store, manipulate, and present the information; 2 . the use of tools to process and move data from one device to another. Based on the subject matter can be seen that the subjects of information and communication technologies can foster digital citizenship in terms of digital communication, digital literacy, health and well-digital and digital security while digital access to do school authorities together with the teacher information and communication technology. Subjects of information and communication technology was imposed by the curriculum in 2006 [3]. But the curriculum in 2013 [4] has removed the subjects of information and communication technology. Then, replace it with new subjects, namely digital simulation which were given just two semesters.

The other side, according to the 2006 curriculum subjects civic education intended that learners have the following capabilities: 1. critical thinking, rational, and creative in responding to the issue of citizenship; 2 . participate actively and responsibly, and act intelligently in the activities of the society, nation and state, as well as anti-corruption; 3 . developing positively and democratically to shape itself based on the characters of Indonesian society in order to live together with other nations; 4 . interact with other nations in the international arena directly or indirectly by utilizing information and communication technology.

The scope of civic education subjects covering aspects as follows: 1. The unity and cohesion of the nation; 2 norms, laws and regulations; 3. Human rights, 4. The need for citizens; 5. The state constitution; 6. Power and politics; 7. Pancasila; 8. Globalization. Based on that scope, the citizenship education can foster digital citizenship in terms of digital ethics, digital law and digital rights and responsibility. While the curriculum in 2013 aimed to prepare humans of Indonesia to have the ability to live as a person and a citizen of the faithful, creative, innovative, and affection and able to contribute to the life of society, nation, state and world civilization. Therefore, the development of civic education based on spiritual attitudes, social attitudes, knowledge and skills. Currently applicable curriculum is the curriculum in 2006 and 2013. The school which does not ready yet to use curriculum 2013 allowed to use curriculum in 2006 during the transition period. But the few next years the curriculum in 2013 will be applicable to all schools.

Digital commerce has not been accommodated by a subject. Meanwhile the data of research conducted in five schools, namely SMK 4, SMK 5, SMK 6, SMK Kristen and SMK Jaya Wisata demonstrate experience in shopping online as follows:

TABLE VIII. ONLINE SHOPPING

\begin{tabular}{|l|c|c|c|c|c|}
\hline & $\begin{array}{c}\text { SMK } \\
\mathbf{4}\end{array}$ & $\begin{array}{c}\text { SMK } \\
\mathbf{5}\end{array}$ & $\begin{array}{c}\text { SMK } \\
\mathbf{6}\end{array}$ & $\begin{array}{c}\text { SMK } \\
\text { KRISTEN }\end{array}$ & $\begin{array}{c}\text { SMK } \\
\text { JAYAWISATA }\end{array}$ \\
\hline Yes & 32 & 38 & 49 & 14 & 23 \\
\hline No & 28 & 22 & 11 & 46 & 17 \\
\hline
\end{tabular}

\section{Online Shopping}

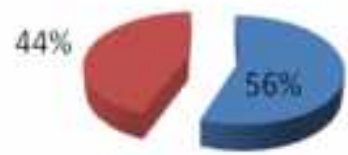

- Yes

No

\section{Role of Civic EducAtion In the Digital CoMmerce}

Government in each country aspires about citizens as expected by the state. It is necessary to set up an education program, one of which is civic education. Civic education is an effort to prepare students to become prospective citizens who understand their role as citizens.

In order to build the capacity / skills students 21 st century (21st century skills), students need to master some skills such as creativity and innovation, communication and collaboration, research skills and information literacy, critical thinking, problem solving (problem solving) and make a decision, citizenship digital (digital citizenship) as well as the concept and operation of the technology [5].

One element in the digital citizenship is a digital commerce. Digital commerce has not got media in school yet. So it needs media for fostering digital commerce. Media were enabled to grow it is civic education. These subjects are very strategic in this country because of the following: First, because legally by law No. 20 of 2003 on the national education system in 37 paragraphs (1) declares that civic education is required to be excellent in the basic education curriculum, middle education and higher education; The second, the scope of civic education are norms, laws and regulations [6]. Within the scope of these may include any related regulations such as the laws of information and electronic transactions, consumer protection laws.

Given the strategic role which owed by civic education, then it is appropriate when every teacher of civic education has knowledge about digital commerce. It can start to grow on civic education teacher candidates when they take part in education. Civic education course curriculum in some campuses prospective teacher had subjects commercial law or business law. The subject is able to adjust the material to the development of world trade today. It will equip future teachers of civic education so that later when the work can play a role in fostering digital citizenship in particular elements of digital commerce.

\section{CONCLUSION}

The development of information and communication technology has brought changes in all layers. The development is also touched students Vocational High School in Surakarta. Research shows that students are digital citizens. Furthermore, how is digital citizenship of students, especially in terms of digital commerce. 
The development of information and communication technology has brought changes in all layers. The development is also touched students Vocational High School in Surakarta. Research shows that students are digital citizens. Furthermore, how is digital citizenship of students, especially in terms of digital commerce. The data show that there were 156 from 280 students or $55,71 \%$, which has made shopping online while only 2 teachers of civic education ever do online shopping and is backed by a lack of knowledge about it.

Civic education can be used as a forum to foster these elements. The debriefing can be given to prospective teachers' education while still studying at the campus prospective teacher.

\section{REFERENCES}

[1] Ribble, Mike and Bailey, Gerald D, Digital Citizenship in School, International Society for Technology in Education, Eugene, Oregon, Washington DC, 2007.

[2] Mossberger, Karen, Tolbert, Caroline J., dan McNeal, Ramona S., 2008, Digital Citizenship, The Internet, Society, and Participation, Massachusetts Institute of Technology.

[3] The 2006 Indonesian Curriculum

[4] The 2013 Indonesian Curriculum

[5] https://www.iste.org/docs/pdfs/20-14_ISTE_Standards-S_PDF.pdf

[6] law No. 20 of 2003 on the national education system 